\title{
The Journal of Architecture
}

\section{Architectural mimicry and the politics of mosque building: negotiating Islam and Nation in Turkey}

\section{Bülent Batuman}

To cite this article: Bülent Batuman (2016) Architectural mimicry and the politics of mosque building: negotiating Islam and Nation in Turkey, The Journal of Architecture, 21:3, 321-347, DOI: 10.1080/13602365.2016.1179660

To link to this article: https://doi.org/10.1080/13602365.2016.1179660

曲 Published online: 17 May 2016.

Submit your article to this journal $2 \pi$

III Article views: 384

Q View related articles $\sqsubset$

View Crossmark data $\nearrow$

4 Citing articles: 1 View citing articles 진 


\section{Architectural mimicry and the politics of mosque building: negotiating Islam and Nation in Turkey}

\section{Bülent Batuman}

\author{
Department of Urban Design and Landscape \\ Architecture, Bilkent University, Turkey \\ (Author's e-mail address: bbatuman@gmail.com)
}

This paper discusses the politics of mosque architecture in modern Turkey. The classical Ottoman mosque image has been reproduced in state-sponsored mosques throughout the second half of the twentieth century. Defining this particular design strategy as architectural mimicry, I discuss the emergence of this image through the negotiation between the nationstate and the 'nationalist conservative' discourse within the context of Cold War geopolitics. Comparing the Turkish case with the Islamic post-colonial world, I argue that the prevalence of architectural mimicry is related to the nostalgia it generates. Nostalgia is a discursive effect of architectural mimicry which is in tune with the nationalist conservative worldview in its relationship to the state's anti-communism. This particular image was taken up by the Islamist AKP in the 2000s, within the context of the global rise of political Islam. In this instance, the same representation took on a different meaning. It functioned as a simulacrum representing the 'nation in Islam' with a claim to authenticity amongst the competing Islamic representations.

\section{Introduction}

On 20 th July, 2012, the Turkish Prime Minister, Recep Tayyip Erdoğan, spoke at the inauguration of the newly built Mimar Sinan Mosque in Atașehir, a rapidly growing district in the Anatolian part of Istanbul. This new mosque was a grandiose replica of classical Ottoman examples, with a 42-metre-high dome and four 72-metre minarets; it was large enough to welcome 12,500 people for prayer (Fig. 1). In addition, it contained conference and exhibition halls, classrooms, shops, a library and a two-storey parking garage. It was built in twenty-two months for an estimated cost of 20 million USD. ${ }^{1}$ Although it was intended to be named the 'Anatolian Great Mosque', this was changed on the Prime Minister's instruction to honour the master architect of Suleyman the Magnificent who lived in the sixteenth century. This choice is not surprising since Sinan has had a mythical cultural status for the political power of architecture: nationalistic nostalgia for a glorious past represented by classical Ottoman architecture signifies imperial power and serves as an 'origin' for a national(ist) architecture. Curiously, the dedicatory inscription signed by the Prime Minister himself explained the significance of 'Sinan the master' as having shown 'the glorious face of a nation and civilisation' with his works. Here, the curious expression of 'a nation and civilisation' is not a case of awkward translation; the Turkish phrase itself refers not to the Turkish nation and Islamic civilisation as two separate entities but rather implies two qualities of one and the same entity.

If we put this odd point aside to come back to later and turn to the mosque itself, according to Erdoğan 
Architectural mimicry and the politics of mosque building: negotiating Islam and Nation in Turkey Bülent Batuman

Figure 1. Mimar Sinan Mosque (2012; photograph by Gülse Eraydın).

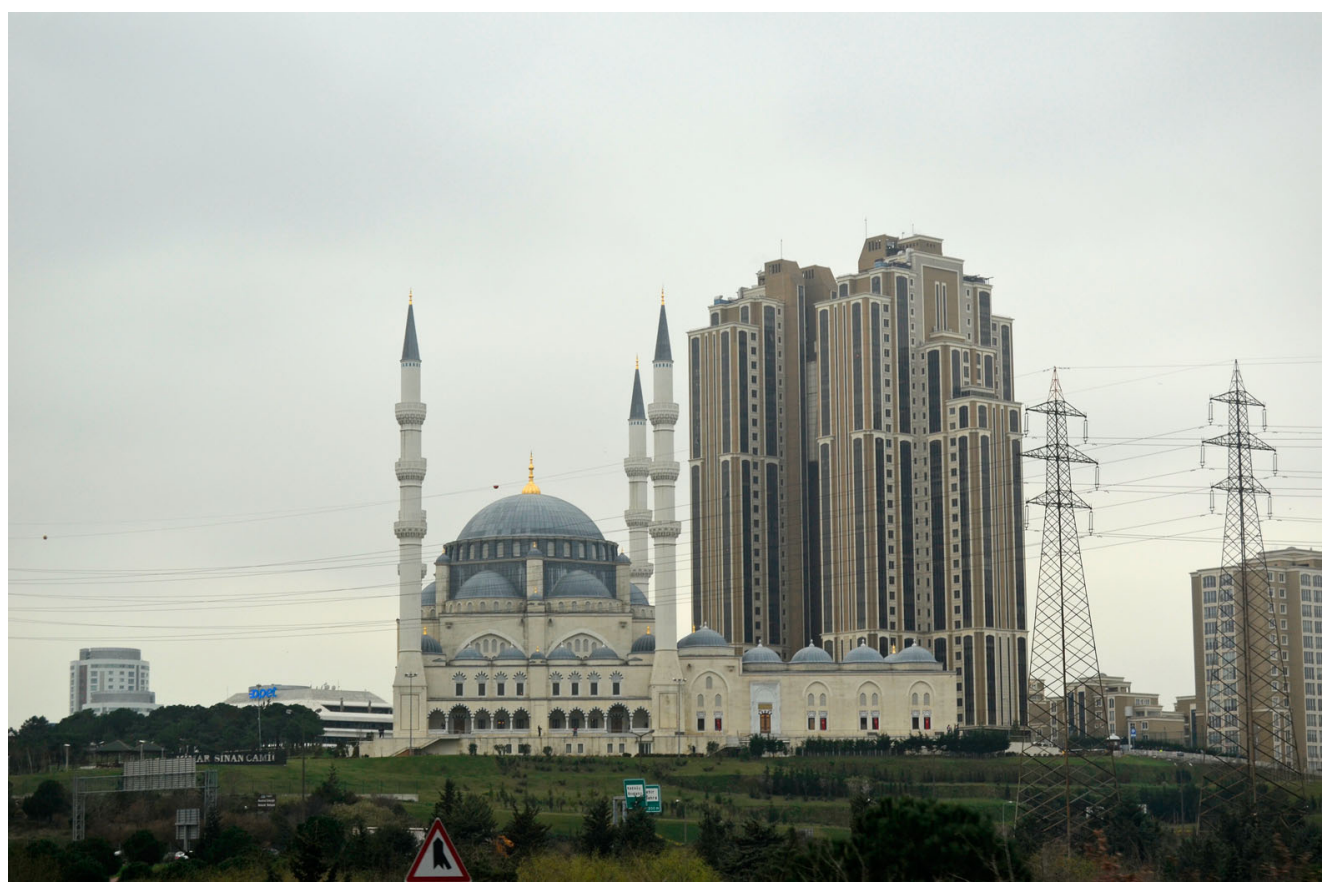

it fulfilled a crucial need in the Anatolian part of the city: 'There is the Fatih Mosque; there is the Sultan Ahmet and the Süleymaniye on the European side. We wished to have a selatin mosque on this side as well.' The choice of the word selatin was significant and very conscious, since the Prime Minister used it twice in his speech. The word is literally the plural form of 'Sultan' and is used to define mosques built by Royal family members in the Ottoman era. Considering that the Maltepe Mosque built between 1988 and 2001 dominated the skyline of the Anatolian side, it was clear that the Prime Minister was not referring to the size of the mosque, but to its political symbolism signifying Ottoman power.

Finally, if we look at those who attended the inauguration ceremony, aside from the group of Ministers, the Prime Minister was accompanied by the President of the Iraqi National Assembly, who embodied significance in terms of the ethno-religious divisions within Middle-Eastern politics. Being the Sunni representative occupying the third most powerful seat (after the Kurdish President and the Shiite Prime-Minister), within the delicate and at times 
tense power relationships in Iraq he was a close ally of Turkey. That is, his attendance was a political gesture towards the Middle East. This was in tune with Erdoğan's victory speech on the night of the elections in June, 2011, where he hailed 'all those in Baghdad, Cairo, Sarajevo, Baku, Nicosia and all other friendly and brotherly peoples who turned their eyes to Turkey' and stated that their victory was the victory of 'the oppressed and the aggrieved': 'Believe me, Sarajevo is victorious as much as Istanbul [today]; Beirut as much as Izmir, the West Bank and Gaza as much as Diyarbakır. Today it is the Middle East, the Caucasus and the Balkans as much as Turkey that is victorious. ${ }^{2}$

These three issues present at the inauguration of Mimar Sinan Mosque - namely the metonymic use of the (Turkish) nation and (Islamic) civilisation, the curious reference to Ottoman rule symbolised with selatin mosques and Prime Minister Erdoğan's political ambitions to be influential across the Muslim world-define the main topic of this paper. I will discuss these three issues through the politics of mosque architecture, specifically the reproduction of the Ottoman classical mosque image. My main argument in this paper is that although imitation of classical Ottoman mosque architecture has been in place throughout republican history and was politically effective after the 1950s, its recent utilisation is significantly different and operates as an instrument in rebuilding national identity with reference to Islam.

Architectural mimicry as a political instrument is not a twentieth-century invention and it has often been deployed within the distinct contexts of colonialism, post-colonial nation-building and even under neo-liberal globalism. Below, I will begin with a discussion of architectural mimicry and its interpretations in the field of architectural history. Next, I will analyse the politics of mosque-building in Turkey and the meanings produced through mimicry. In doing this, I will refer to three particular cases from two different periods. I will present Kocatepe Mosque as the prime example of mimicry for nostalgia with reference to the work of Homi Bhabha. Then I will discuss two recent examples, both of which were proposed for Istanbul within the Islamist moment: the unbuilt project for Taksim Square and the Çamlıca Mosque, now under construction. I will argue that the deployment of architectural mimicry to reproduce the image of classical Ottoman mosques produces a distinct meaning in the current global context.

To support my argument, I will briefly discuss the reflections of the 'Islamic revival' in mosque architecture. I define the return to traditional architectural features in mosque architecture as reOrientalism, which supports the idea that there is one whole entity called Islam and affirms its construction as the 'other' in the Western gaze. In contrast, the mimicry of Ottoman mosque architecture at the current moment has to be understood differently, since it implies a singularity of the Ottoman mosque type within the current global context. I discuss the mimicry of Ottoman mosques as a case of self-Orientalism, which differs from re-Orienalism with its claim to differentiate itself from other representations of Islam to be recognised not only by the Western gaze but also the Islamic audience. 


\section{The politics of architectural mimicry}

Mimicry was an important component of colonial architecture. The use of already existing architectural idioms within colonial encounters has been scrutinised by scholars since the late 1980 s. $^{3}$ The colonisers often visually reproduced traditional architectures of the colonized, at times to display power (particularly in the World Fairs) and at times to inflict assimilation in the colonies. ${ }^{4}$ Sometimes western architectural forms were imposed on the colonies as nationalist signifiers to maintain an imperial image in the eyes of both the colonisers and the colonised. ${ }^{5}$ The need to uphold identification by colonial subjects with a colonial power led to the operation of architectural mimicry as a domain of negotiation and hybridisation. Homi Bhabha has famously discussed mimicry as an ambivalent relationship between the coloniser and the colonised. Accordingly, the act of mimicking the coloniser is simultaneously a disciplinary colonial practice and one that 'discloses the ambivalence of colonial discourse and disrupts its authority'. ${ }^{6}$ I find Bhabha's definition of the concept useful for the case of mosque architecture in Turkey, where what is at stake is not the relationship between a subject position and the colonial 'other' that defines it, but one between a subject position and a constitutive referent, which itself is a representation-of the sixteenth-century Ottoman Empire.

Architectural mimicry was also a major strategy in nation-building and modernisation, where postcolonial nation states admired International Style modernism imported from the West as an architectural proof of cultural modernisation. This was already a major strand of national development in republican Turkey, following its foundation in 1923. Modernism was seen as a cultural manifestation of nation building throughout the inter-war period. ${ }^{7}$ Hence, ideas, schemes and forms related to urban development and architectural style were transferred from Europe. ${ }^{8}$ In the post-war era, Turkey was also among nations seeking integration with Western capitalism and importing the International Style as a globally valid signifier of American-type modernisation. ${ }^{9}$

The last two decades of the twentieth century also witnessed the utilisation of architectural mimicry as an effect of globalisation; this time particularly through the importation of architectural typologies serving tourism and consumption. ${ }^{10}$ Shopping arcades, tourist resorts and theme parks began flourishing in differing parts of the globe; moreover, with the advent of post-modernism, the architectural forms in circulation also juxtaposed images derived from a variety of historical styles. ${ }^{11}$ This trend was also embraced in Turkey: tourist resorts as well as the newly emerging gated communities imitated traditional residential architecture, claiming to seek a 'Turkish identity'. ${ }^{12}$

Thus, architectural mimicry has a history of more than two centuries. Its theorisation, on the other hand, has not been integral and has mostly focussed on specific historical contexts. My aim in this paper is to contribute to these debates through the comparative analysis of architectural mimicry within two different historical periods in Turkey: first, the postwar moment and the rise of the Cold War and second, the current Islamist moment. Before going into the discussion of mosque architecture in Turkey, it is crucial to emphasise that the mimicry 
of sixteenth-century Ottoman mosques in the republican era did not involve the exact replication of particular grandiose mosques. Bianca Bosker has recently discussed architectural mimicry in contemporary China, where actual buildings of the Western world are imitated in detail. ${ }^{13}$ Bosker argues that this is an attempt at symbolically conquering the West's past and present; it also relates to Chinese culture's appreciation of a 'good copy'. In the case of Ottoman mosque replicas, however, it is not particular mosques but a general idea of a classical Ottoman mosque that is imitated. It never involves an exact replica of a particular mosque but rather favours an image produced with components of different examples: the plan of one mosque, the number of minarets of another, etc. This allows for a major difference from exact replication: the product of mimicry is not perceived as imitation but as authenticity. However, the claim to authenticity through mimicry is a complex issue. Although the intention is to repeat the original, mimicry continually produces 'its slippage, its excess, its difference'. ${ }^{14}$ The outcome is 'almost the same, but not quite'; Bhabha defines this as the ambivalence of mimicry.

I argue that mimicry of the classical Ottoman mosque produces different meanings in different historical contexts, which can be differentiated precisely through their relationship to the ambivalence of mimicry. It emerged as an architectural idiom of the nationalist-conservative worldview in the 1950s, which operated through the mechanism of nostalgia. Here, nostalgia is a discursive effect of architectural mimicry, acknowledging its failure as representation: the painful reminder that the golden age (of the glorious Ottoman Empire) is long gone. However, mimicry as a state project of Islamism in the 2000s is radically different, rooted in the disavowal of such failure and the claim to rebuild the glory of the past in today's conditions. As I will show, this leads to the emergence of the Ottoman mosque as a simulacrum: a representation envisaging the gap between the original and itself as irrelevant.

\section{The primal encounter: Kocatepe Mosque}

In order to understand the significance of constructing a twentieth-century representation of the Ottoman Empire in its heyday, it is necessary to discuss briefly the uneasy relationship between Islam and nation in Turkey. The republican ethos was built on a foundational disavowal of the Ottoman past, particularly its Islamic identity. ${ }^{15}$ The Ottoman Empire was conceived as the embodiment of backwardness representing everything that had to be overcome in order to 'catch up with' Western modernity. The national identity was invented with reference to a distant Turkish history preceding the Ottomans. Yet, when it was necessary, Ottoman references were also put to use, with an emphasis on Turkishness downplaying Islam. ${ }^{16}$ A good example illustrating this was that of Sinan, who was re-invented as a proto-modern genius architect in the 1930s in order to utilise architecture in forming the national ethos. ${ }^{17}$

The radical secularism of the single-party regime that lasted until the end of the Second World War resulted in the strict control of the religious domain by the state. One of the first measures taken by the young nation state was the establishment of 
Figure 2. Unbuilt project for Kocatepe Mosque, designed by Vedat Dalokay (source, Vedat Dalokay Archive).
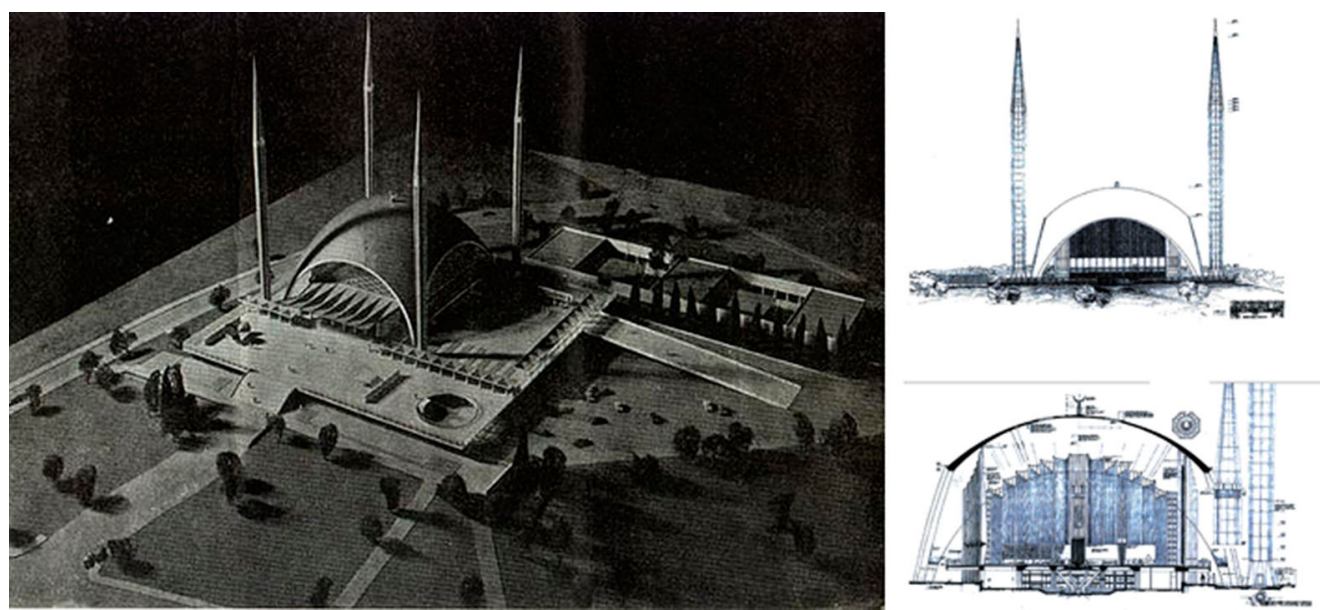

the Directorate of Religious Affairs in 1924 to control all religious activity in the country, including the administration of its 12,500 mosques. ${ }^{18}$ Within this context, mosque building was merely a response to communal needs. The mosques built in this period were relatively small in size and no major examples were executed. The builders followed local traditions in the provinces and deferred to the existing Ottoman mosques in the larger cities. Mosque architecture was not a part of the cultural manifestations of nation building throughout the early republican years, which made Turkey an exceptional case among the nation states established in countries with Islamic populations. This in turn resulted in the lack of a debate on the iconography of the mosque until the 1950s. That is, although Ottoman mosque architecture was a source of reference, this was not mimicry as conscious imitation but continuity of building traditions.
The Democrat Party (DP), which came to power in 1950, aimed for reconciliation with the Islamic identity of the country. One of the first actions of the government was to allow the performance of the call to prayer in Arabic. Although Islamic ideas flourished anew under the Democrats, Islamism was still not allowed to emerge as an independent political force and instead found its way into the encompassing ideological current labelled 'nationalist conservatism'. ${ }^{19}$ This originated mainly from a circle of intellectuals representing conservative thought against the radical modernisation efforts of the early republican years. ${ }^{20}$

With the end of single-party rule and the rise of Cold War geopolitics, the nationalist conservative current successfully blended nationalist and Islamist streams on the common ground of anti-communism. This ideological amalgam merged opposition to radical modernism and secularism (as well as 
any strands of leftism) while emphasising the necessity of a powerful state to defend national unity. Hence, it was instrumental in expanding state hegemony while presenting itself as an oppositional discourse. In this context, political Islam never positioned itself in direct confrontation with the state, but rather negotiated its demands through the nationalist conservative agenda. The sixteenthcentury Ottoman Empire at the zenith of its power was the prime referent for the nationalist conservative imagination, representing the golden age of Nation and Islam.

Although the Democrat Party was a successor the republicans in terms of secular modernisation, it did not hesitate to utilise the mosque as a symbol of national identity. Under the Democrats the mosque gradually gained political significance. One of the two hot topics in this regard was Hagia Sophia: its secular status as a museum began to be disputed as early as $1952 .{ }^{21}$ The second was the proposal to build a mosque in Taksim Square for which a building plot was allocated by the municipality in $1955 .{ }^{22}$ Whilst these endeavours were frustrated when military intervention toppled the Democrats in 1960, the nationalist-conservative pressure on right-wing parties continued in the following decade and proved successful with the allocation of a new building plot by the government in 1965. The issue was even a topic during the local elections in $1968 .{ }^{23}$ Both Hagia Sophia and the Taksim Mosque debates prove that the mosque as such had an ideological content by the 1950s. Moreover, these two issues also illustrate the growing influence of nationalist conservatism as an oppositional-yet-hegemonic discourse. $^{24}$
Finally, if we consider the government's attitude regarding the ideological aspect of mosque architecture, a propaganda booklet for the 1957 elections provides us with relevant material. This booklet was entitled 'Towards Great Ankara' and it focussed on the development of the capital city under the Democrats. ${ }^{25}$ The modernist overtone of the publication was visible in the pairs of photographs showing the before and after conditions of various parts of the city as well as the frequent use of photographs of models of new buildings designed in International style architecture. Within the section illustrating the new buildings in order, a striking photograph showed the model of the newly designed Kocatepe Mosque (Fig. 2). The mosque had a modern design and its site was in Yenișehir ('new city'), the modern district constructed in the republican era. Yenissehir was associated with republican modernisation with its modernist planning and the location of the government quarter as its centrepiece. $^{26}$

Hence, building a mosque here was a political gesture. Located on a hilltop across from Atatürk's Mausoleum, the 'greatest mosque of the republican era'-as the caption of the photograph contended -was realised under the patronage of the Prime Minister, Adnan Menderes. ${ }^{27}$ The modernist design of the mosque, which was presented by the government with pride, was quite controversial for conservative circles. Achieved through an architectural competition won by Vedat Dalokay and Nejat Tekelioğlu, the proposed scheme followed the traditional mosque layout in its central dome, minarets and physical organisation. Yet, its innovative structure made up of a thin concrete shell defined the main 
prayer hall as a unified space flooded with light from all sides. The corners where the shell touched the ground were marked with four slender minarets, a number familiar from Ottoman monumental mosques, yet their abstracted forms, resembling rockets, were perceived as quite alien. ${ }^{28}$

In fact, the modernist interpretation of Kocatepe Mosque was in tune with the international trends of the post-war years, where the newly established nation states in Islamic countries deployed similar approaches. Major examples of this trend were the Masjid Istiqlal in Jakarta, which was the winning project of the 1955 competition, and the Masjid Negara in Kuala Lumpur, which was designed in 1957. The following decade also saw the continuation of the same trend with the examples in the Capitol Complex in Dhaka designed by Louis Kahn in 1962 and the King Faisal Mosque in Islamabad, the design competition for which was won by Vedat Dalokay. Curiously, whilst these modernist mosques were being built as symbols of optimism regarding modernist nation building in Islamic societies, the Kocatepe project was criticised by nationalist conservative circles. Although these criticisms were not raised vociferously against the DP government, they gained impetus after the coup in 1960. Perceived as a state project representing the reconciliation of Islam and national identity in the 1950s, the mosque assumed a new representation after the coup. Now, it was identified with the military intervention within the nationalist conservative imagination and understood as yet another symbol of radical modernism. Whilst the mosque had already become an ideological signifier, its architecture was assuming an ideological content for the first time. As already indicated, its minarets were likened to space rockets and construction was delayed. ${ }^{29}$ Finally the project was abandoned and its foundations were destroyed in 1966. A new project, which was a colossal Ottoman replica mostly imitating Sinan's Şehzade Mosque, was approved in 1967 after a speedy competition and its construction was begun. ${ }^{30}$ Not only the style but also the size of the mosque was dramatically changed to house ten times as many people (Fig. 3). ${ }^{31}$

The termination of the modernist project for Kocatepe Mosque was a shock for the architectural community in Turkey. ${ }^{32}$ Moreover, it was a decisive moment, giving birth to the mimicry of classical Ottoman mosque architecture. This primal encounter with the modernist mosque as such resulted in the ideological recognition of architecture: from this point onwards the symbolism of the mosque was not only about its location in the city but also its architecture. The mimicry of Ottoman classicism emerges here as an architectural idiom of nationalist conservatism negotiated with the state. As I have discussed above, the imperial image of the sixteenth century presented the perfect combination of nation and Islam, fitting well with the representation of the powerful state. For the nationalist conservative imagination, this image was nostalgic: it longed for the golden age of the nation but with an awareness that the moment had long gone. Thus, nostalgia is a discursive effect of architectural mimicry; it reflects awareness regarding its failure as a representation. If we remember Bhabha's definition of mimicry as the colonised's attempt to imtate the colonial, the result is 'almost the same but not quite': mimicry 


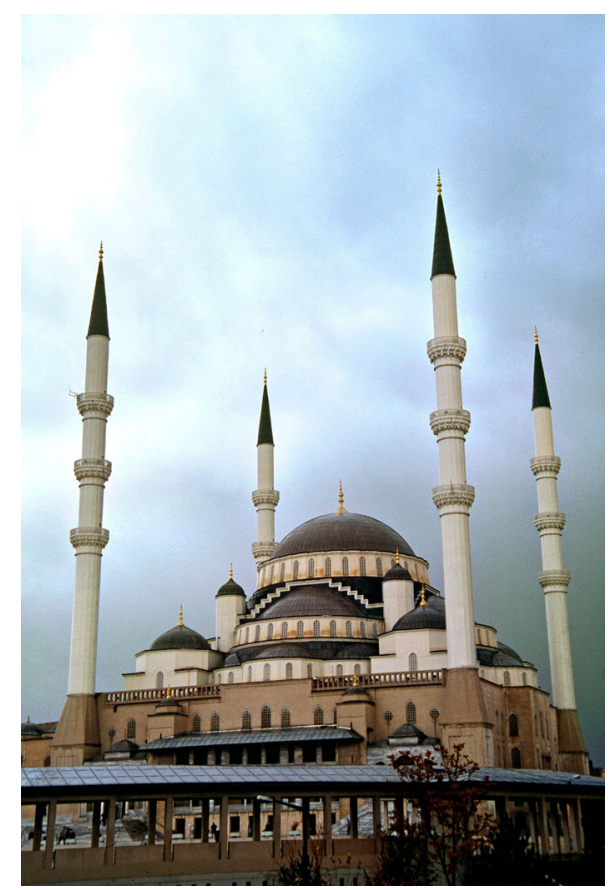

constanly troubles the coloniser's authority by minimising its difference and simultaneously fails the colonised's capacity for fully assuming the identity of the coloniser. In a similar fashion, what it at stake in the case of mimicking classical Ottoman mosque architecture is the desire of the nationalistconservative subject to imitate the glory of the imperial image. Although replication is achieved visually, there is an essential failure here. What makes the classical Ottoman mosques historically monumental is not their size but their innovative achievements in terms of construction techniques.
The reinforced concrete structures imitating the forms of stone architecture of the sixteenth century, silently confirms their inferiority in relation to the originals they are imitating. ${ }^{33}$

Nevertheless, the question we should ask is why mimic the Ottoman mosque instead of inventing some other architectural idiom? If we look at the global scene regarding mosque architecture, it is possible to observe a certain shift in the late 1960s. As I have stated above, modernist interpretations of traditional mosque forms were embraced by both secular modernist states such as Egypt and Indonesia, and Islamic modernist ones such as Malaysia and Pakistan in the 1950s and 60s. However, the end of the 1960s witnessed the decline of the secular nationalist governments in the post-colonial world and the rise of what would later be called the 'Islamic revival'. ${ }^{34}$ The disappointment of the Arab-Israeli War in 1967, disillusionment with nationalist governments and the suppression of left-wing movements within the Cold War context led to the rise of Islam both as an oppositional movement and an instrument for right-wing governments. ${ }^{35}$

It is striking to see that mosque architecture also distanced itself from modernism and turned to searching for identities in specific cultural contexts. In the Islamic post-colonial world, the mosque as a national symbol was stylised with reference to imagined pre-colonial identities. Examples of this kind are the King Abdullah Mosque in Amman (19821989), King Hassan II Mosque in Casablanca (1986-1993) and the University of Indonesia Mosque in Depak (1987). ${ }^{36}$ Moreover, local architectural features began to circulate and led to the
Figure 3. Kocatepe Mosque dominating the skyline of Ankara (photograph by Mehmet Özer). 
emergence of trans-national combinations as seen in the examples of the Sultan Salahuddin Abdul Aziz Mosque in Shah Alam, Selangor (1974-1988) and the International Islamic University Central Mosque in Chittagong, built in the late 1990s. In this regard, so-called Islamic revivalism found its architectural expression in 're-Orientalism', which totalised mosque architecture and supported the idea that there is one whole entity called Islam. ${ }^{37}$ Examples of such essentialism can be observed in Sadat's Egypt, Suharto's Indonesia, Mahathir's Malaysia and Zia-ul-Hak's Pakistan. In these Islamic countries, states gradually increased the influence of Islam as a cultural means to promote the dominance of 'Islam in nation'. Such a strategy for Islamic nation building found its reflection in state-sponsored mosques assuming traditional forms and features. ${ }^{38}$ In cases such as Kuwait, Oman, Jordan and Morocco, where dynastic continuity was at stake, this approach was already dominant, even if there were cases of modernist mosques sponsored by private patrons.

Although there is a parallel with the post-colonial examples above, the absence of a colonial past in the Turkish case creates an important divergence. The nationalist conservative imagination in Turkey, similarly to right-wing discourses in different cultural contexts, envisages a glorious past and seeks revivalism in cultural domains. Yet, in the Turkish case, the absence of a colonial encounter led to the failure of conscious contemplation regarding architectural forms until the Kocatepe Mosque. This was the reason for the almost mechanical continuity of mosque building in terms of architecture in the republican period. The hostility triggered by the anxiety of losing the glory of the Ottoman past directed itself to the modernist mosque as soon as it emerged as an intended national symbol. Although the modernist mosque design of Kocatepe was approved and even proudly embraced by the Democrats in the 1950s, it was re-presented as an alien condition after the military intervention in 1960. In other words, the emergence of alternative architectural idioms was blocked by the nationalist conservative imagination, culminating in the architectural mimicry of sixteenth-century mosque architecture. $^{39}$

Architectural mimicry as displayed in Kocatepe Mosque turned the classical Ottoman mosque into a discursive referent. The General Directorate of Foundations, the republican institution responsible for the operations of centuries-old endowments, provided blueprints in different sizes (published in 1973) to guide the local production of mosques across the country. This lowered costs (obviating architectural fees) but also significantly reduced the chance of alternative designs being executed. This new discursive referent even generated a new historiography. The Directorate of Religious Affairs published an album for the $50^{\text {th }}$ anniversary of the republic, which claimed to represent the mosque architecture of the republican period. ${ }^{40}$ Whilst the album contained a selection of 314 mosques out of the 30, 000 built in that fifty-year period, it excluded the small number of modernist mosques.

\section{The rise of political Islam as an independent force}

Turkey experienced another military coup in 1980. The main objective of the coup was to suppress 
the growing socialist movements; Islam was seen as a major instrument towards this end and the mosque, unsurprisingly, as the utmost symbolic means. For instance, it was decided to build an Islamic centre with the second largest mosque in Ankara at the Middle East Technical University, a hotbed of socialist student organisations, as early as $1981 .{ }^{41}$ In the same year, the deadlocked construction of Kocatepe Mosque was handed over to the Turkish Foundation of Religious Affairs, which was established as a non-profit organisation to support the Directorate of Religious Affairs in 1975 and was granted tax exemption in 1978. Soon after the transfer of the construction work to the Foundation, coup's leader, Kenan Evren, visited the construction site and stressed the importance of finishing the mosque at once. ${ }^{42}$ With the military regime prioritising the mosque, a construction company was established by the Foundation in 1983. This approach proved successful and the mosque was finished in 1987. ${ }^{43}$

After the inauguration of Kocatepe Mosque, an ambitious project for building large-scale mosques was undertaken. The Foundation supported the construction of monumental mosques in Istanbul, Maltepe (1988), Adana (1988), Konya (1988) and Mersin (1988), all of which were finished within the next decade. These mosques were intended to be the largest in their respective cities (Maltepe Mosque being the largest in the Anatolian side of Istanbul). Moreover, the Foundation prepared new blueprints for smaller mosques to assist local citizens in building them (Fig. 4). Needless to say, all of these were replicas of classical Ottoman mosques.

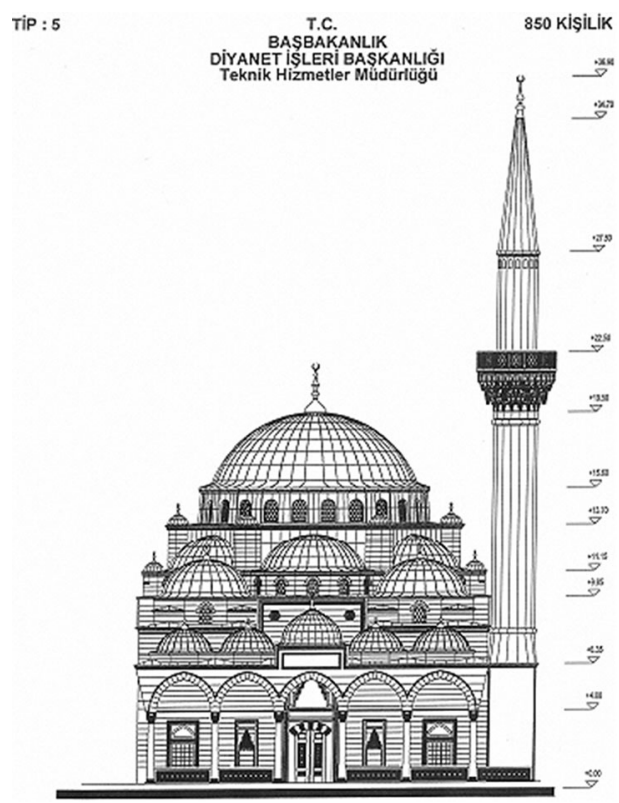

The constant interplay between the nationalist conservative worldview and the state enabled the exploitation of conservative - if not Islamic — demands for the regulation of cultural life as means of advancing social control by the state. However, the equilibrium between popular demands along Islamic lines and the states' intention to use Islam as a means of social control was soon broken down to the advantage of the former with the end of the Cold War and the increasing influence of neo-liberalism. Islam began to assume a global identity as a populist response to neo-liberalism across the Third World. With the dismantling of welfare mechanisms, Islamic networks of solidarity, successfully deployed
Figure 4. Architectural blueprints provided by the Directorate of Religious Affairs for mosque building (source, Directorate of Religious Affairs). 
by the Ikhwanul Muslimin ['Muslim Brotherhood'] in the Middle East, began to be more influential than ever. Especially where authoritarian regimes were marked by corruption and failure to maintain popular consent, political Islam rose as the major oppositional power.

A similar process occurred in Turkey. Emerging for the first time as an independent political force, the Islamist opposition broke away from the nationalist conservative elements and developed a radical critique against the status quo. The Islamists gradually expanded their popular base with successive electoral victories, especially in the local government, taking over the local administrations of the three major cities in 1994. Although I will not go into the details, what is crucial is the transformation of the Islamist movement in the late 1990s. This transformation was a result of, on the one hand, military intervention in 1997 and, on the other, experience in local and central governments leading them to reconciliation with the market if not with the state. In 2001, the Islamists split into two factions. While the older generation maintained the radical Islamist discourse of the 1990s, the younger generation led by Erdoğan established the Justice and Development Party (AKP). The AKP broke away from the anti-capitalist, anti-Western discourse and embraced an agenda of democratisation in the face of a constant threat from the military. From then on, the party strengthened its hegemony through the zealous fulfillment of neo-liberal market demands and a populist welfare system utilising Islamic social networks. The Islamist opposition was absorbed into the system, which was a 'passive revolution' in Gramscian terms. ${ }^{44}$
However, before discussing the AKP era, it is necessary to consider the growing influence of the Foundation of Religious Affairs, which proved to be a powerful financial tool for religious work and particularly mosque building. While the Foundation undertook the construction of 'monumental mosques' in the major cities in the late 1980s, an unexpected development drastically changed Turkish foreign policy and significantly broadened the Foundation's functions. The collapse of the Soviet Union and the emergence of Turkic states in Central Asia were seen as an opportunity by the Turkish political establishment. Turkey was the first country to recognise these new states formally and trade relations were quickly established. Such a move towards establishing close ties with these new-born nations rested on an optimistic idea that Turkey could become the leader of the 'Turkic world', and the Foundation became a major tool in developing cultural influence abroad. With the emergence of new territories in which to build mosques, the funds allocated to mosque building considerably increased after $1990 .{ }^{45}$ Although the Foundation had already begun working in countries with significant populations of Turkish migrants, such as Germany and Australia, the newly independent Turkic states were quite different. Now the audience was not a diasporic community of Turkish citizens, but whole nations-in-building, imagined as an extension of the Turkish nation. ${ }^{46}$

Although the Turkish state was eager to organise the Turkic states around an ethnic identity, this strategy soon proved unsuccessful since the new republics rejected Turkey's pan-Turkism. In the following decade, the focus of foreign policy regarding 
Central Asia changed, with an emphasis on Islam under the AKP. ${ }^{47}$ This shift in the way of looking at the peoples of Central Asia is not merely a strategic manoeuvre but an overall alteration of the definition of the nation. After 2009, and especially with the victory speech of Prime Minister Erdoğan in 2011 quoted previously, the AKP has altered the Turkish foreign policy along Islamist lines. Whilst some authors label the new foreign policy of the AKP as 'Neo-Ottomanism', others argue instead that this is a 'Pan-Islamist' approach. ${ }^{48}$ As this debate is beyond the scope of this paper, it is sufficient to point out that the advancement of architectural mimicry gains a new meaning within this context. Whilst it represents 'Islam in nation' domestically, it emerges as a signifier of 'nation in Islam' globally. Clearly, in the AKP's vision, what is at stake is not a nation, but the nation-in-Islam. Moreover, the existence of extremist Islamic movements in Central Asia made the Turkish organisation for Religious Affairs as a secular and state-controlled mechanism a preferable choice as contrasted with Saudi influence in the region. ${ }^{49}$ In this context, with Islam as the central element in the AKP's active foreign policy in the Muslim world, the Ottoman mosque emerged as an authentic brand.

Nevertheless, the idea of 'nation in Islam' also resonates at home and invokes the redefinition of the nation. As illustrated with Erdoğan's dedicatory inscription on the Mimar Sinan Mosque quoted at the beginning of this paper, the presentation of Turkishness and Islam as qualities of the same entity is significantly different from the republican definition referring to a secular and ethnically homogeneous body. Whilst the Kemalist state invented the term ulus in the 1930s to define the secular nation, the ideologues of the AKP use millet, a term of Arabic origin implying a community of shared religion. Although the term has been used in the twentieth century, especially by nationalist conservative intellectuals as a reaction to linguistic Turkification, the reference to millet by the AKP is significantly different. The millet is now envisaged through 'self-Othering': denoting a majority which had been oppressed by the elite minority throughout republican history. The attempt to rebuild the nation as a millet also inevitably made use of the mosque. While 1,000 new mosques are built each year, older mosques without a dome and a minaret are torn down and replaced with larger Ottoman replicas. In addition, urban regeneration projects in squatter areas propose new residential environments which always include mosques. The Mass Housing Administration built 480 mosques between 2005 and 2013 along with 600,000 housing units. ${ }^{50}$ This means the creation of new residential areas designed with their mosques as key social spaces in their organisation.

The Directorate of Religious Affairs, together with the Turkish Foundation of Religious Affairs and the Foundation for Religious and Social Services, ${ }^{51}$ have been organising campaigns to promote the mosque as a social space and encouraging imams to become the imams 'of neighbourhoods instead of mihrabs'. The new mosques have expanded programmes with spaces for social and cultural activities, and imams are even allowed to improvise with the socialisation of the mosque space. ${ }^{52}$ The government also utilised the mosque as an environment to pacify, if not assimilate differences to create the 
harmonious Islamic millet. The two major social groups targeted through these policies were the Kurds (with an estimated population of 12 million) and the Alevis, a large religious minority of 10-15 million. ${ }^{53}$

\section{Mimicry beyond nostalgia: the ideological simulacrum}

The freedom enjoyed by religious groups during the rule of the AKP also contributed to the emergence of the mosque as a signifier of differences. For the first time, mosque architecture outside architectural mimicry began to receive popular approval. Although there were small examples before, the 2000s witnessed the rise of heterogeneity in architectural vocabulary with the emergence of devout patrons (Fig. 5). The stylistic range of new mosques included modernist examples as well as historicist interpretations of traditional mosques and schemes imported from different cultural contexts. Here, it is interesting to note that such heterogeneity also legitimised the hitherto marginal lineage of modernist mosque design and a new generation of prominent Turkish architects (such as Nevzat Sayın and Emre Arolat) identified the opportunity to put forward innovative proposals. ${ }^{54}$ Whilst these experiments with mosque architecture compose a small portion of ongoing production, they triggered debates outside the architectural community for the first time. Through a number of symposia, the Directorate sought alternatives to the innumerable poor imitations of classical mosques, but without damaging the association with the Ottoman past and its glorious symbolisation of millet. ${ }^{55}$
Within this context, where even the Directorate was seeking new architectural idioms, it is curious to see that the state-sponsored monumental mosques reproduce the same image as illustrated by the Mimar Sinan Mosque. The question we have to ask here is this: how should we interpret architectural mimicry beyond nationalist conservative nostalgia; what does it represent under the conditions of stylistic heterogeneity? I will answer this question after discussing two recent controversial mosque projects.

As I have mentioned earlier, building a mosque in Taksim has been a major component of Islamist imaginary. Erdoğan was a fervent supporter of the idea during his time in office as the Mayor of Istanbul and brought the issue onto the agenda once again after the 2011 general elections. ${ }^{56}$ In May, 2012, Ahmet Vefik Alp, an architect politically affiliated with the Nationalist Action Party (MHP) put forward a mosque proposal for Taksim. ${ }^{57}$ Claiming that he was hired by the Taksim Mosque Building Society two years earlier, Alp criticised the tradition of 'fake replicas of the 500 years old grand architecture of the Master Architect Sinan' and argued that his 'avant-garde approach' would 'ease the [secularists'] opposition to a new mosque in Taksim' ${ }^{58}$ According to him, his proposal signifies 'a meaningful breakthrough through the delicate interpretation of modern mosque architecture while preserving the symbolic values of the mosques of the Ottoman times'. Labelling the project not as Taksim Mosque but 'Mosque of the Republic \& Museum of Religions', Alp sought to represent the cosmopolitan identity of Istanbul through the juxtaposition of non-Islamic faiths and republican secularism. Con- 


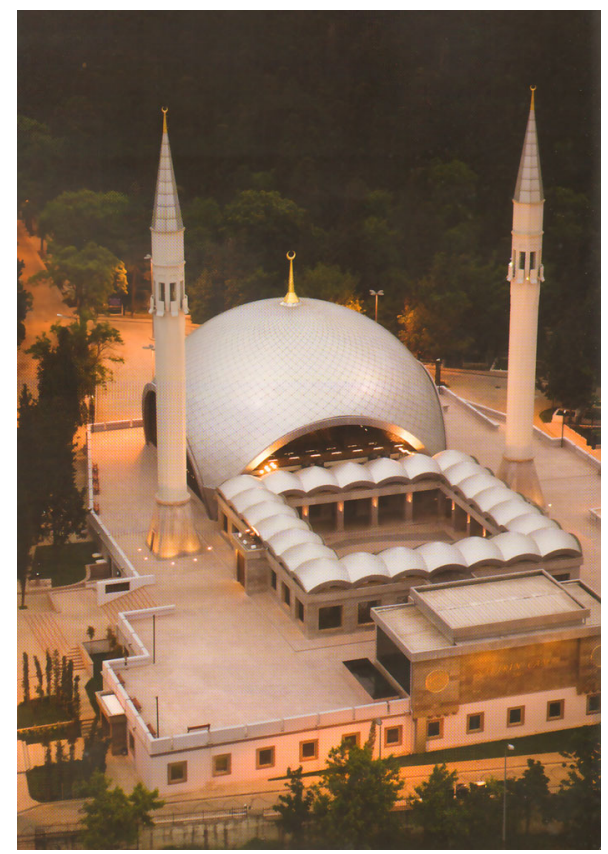

taining spaces for worship by Christians and Jews, as well as a library, this project suggested creating a programmatic association of religions. Moreover, carefully arranged drawings presented the proposed mosque in communication with the historical Aya Triada Church and the Republican Monument (Fig. 6).

In this proposal, the space for worship was designed as a spherical glass dome, covered by a self-supporting structure composed of an irregular mesh, rising from behind the historical Maksem (water distribution chamber). The sphere was situated on top of a platform with Y-shaped supports resembling bodies raising their arms to the sky. Viewed from the top, the composition revealed a crescent and a star, the elements of the Turkish flag. The sphere, according to the designer, echoed the rising sun during daytime and the rising moon at night. The only minaret was finished not with a traditional cone but with a group of crescents referring to the traditional Ottoman ensign, which is also used as an emblem by the MHP. The Museum of Religions, which was to be located in the basement, comprised three floors in which Judaism, Christianity and Islam were arranged on each floor, with this particular order of 'ascendancy', privileging Islam over the others.

Alp's proposal was an attempt simultaneously to overcome political conflict around the controversy over a mosque in Taksim and professional debates around mosque design, dismissive of classical replicas. The design proposed to replace mimicry with a post-modern strategy substituting traditional iconography with symbolic articulations. This proposal should be seen as an effort to achieve a contemporary idiom for nationalist conservatism, re-balancing nationalism and Islam with reference to the global heterogeneity in mosque architecture. Nevertheless, the project was rejected by Erdoğan for being 'too modern'. ${ }^{59}$ Almost a year later, in April, 2013, Alp announced that work was in progress on modified versions following suggestions by the Prime Minister conveyed indirectly. In September, he published the revised project, in which the most visible change was the removal of the multiple crescents on the minaret: although the new proposal had been submitted to
Figure 5. Sakirin Mosque in Istanbul (2009; photograph by Benno Thoma, courtesy of Zeynep Fadillioglu Design). 
Architectural mimicry and the politics of mosque building: negotiating Islam and Nation in Turkey Bülent Batuman

Figure 6. Ahmet Vefik Alp's mosque proposal for Taksim (courtesy of Alp Architects); note the Aya Triada Church in the background.
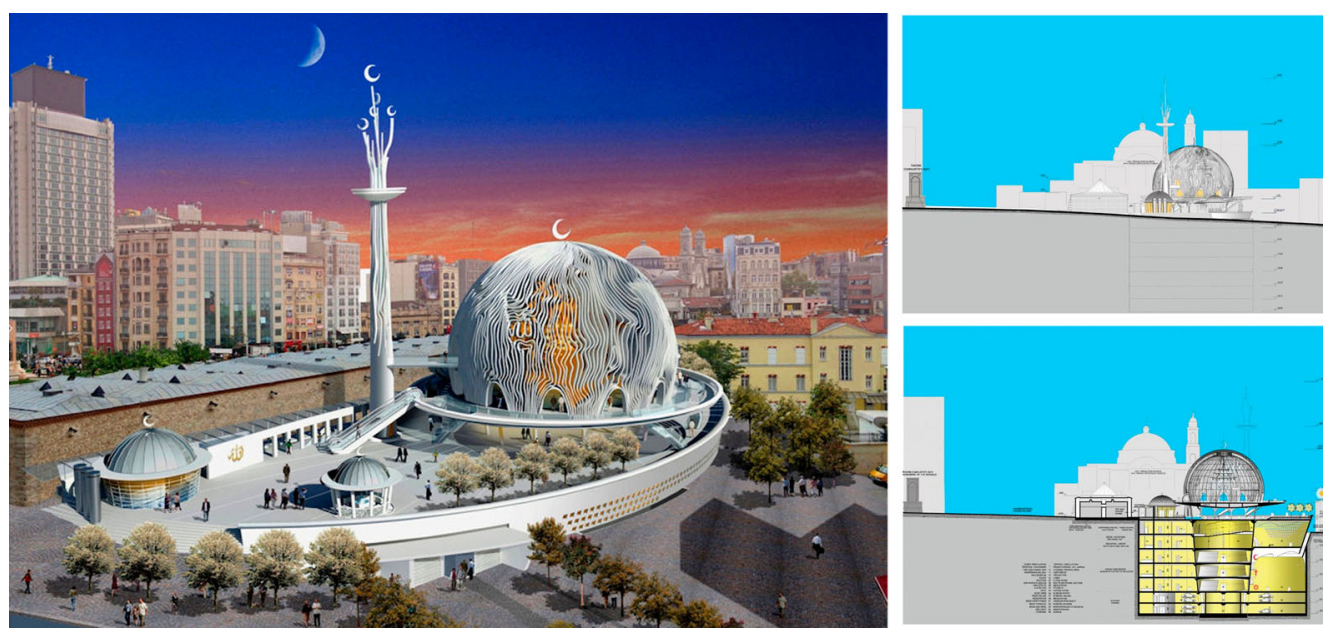

the Prime Minister, there was no sign of a positive response. $^{60}$

On $29^{\text {th }}$ May, 2012, the $559^{\text {th }}$ anniversary of the conquest of Istanbul, Erdoğan announced that a monumental mosque was to be built on Çamlıca hill: 'among the largest in the world and visible from everywhere in the city'. ${ }^{61}$ This district is closely associated with Erdoğan himself, since his residence is located there. Two months later an architectural competition was announced for the mosque and participants were given only forty days to submit their proposals. The Competition brief explicitly asked the entrants to come up with proposals 'reflecting Ottoman-Turkish architectural style, connecting tradition to the future and adding an original link to our culture's chain of tradition' [emphases added]. ${ }^{62}$ The Competition was boycotted by the Chamber of Architects and prominent professionals, questioning both the legitimacy of such a colossal mosque and the reliability of the Competition, whilst leading scholars declined to join the jury. The results of the Competition further fuelled the debates since no project was awarded first prize and two were awarded second prizes. One of the second-prize winners featured an Ottoman replica while the other was a modernist scheme: and the Prime Minister himself decided that the former was to be executed. Here, it is necessary to discuss both of the projects, since they represent the two seemingly irreconcilable trends in Turkish mosque architecture.

Two young architects, Süleyman Akkaş and Nihal Şenkaya Akkaş, defined their modern proposal as a statement illustrating 'why the selected project [a replica] should not be constructed and showing the right way of designing in the light of $21^{\text {st }}$ - 
century contemporary architecture'. ${ }^{63}$ The explanatory note accompanying the project's illustrative material argued that centrality in Ottoman mosque plans was an outcome of the structural requirements to create the particular monumental silhouette, and that contemporary technology made it possible to create innovative envelopes overcoming structural necessities defining the central dome. Under these circumstances, it is possible to create 'a unified prayer hall uninterrupted with columns or arches'. Hence, the designers proposed a vault-like shell comprising three sets of folded plates defining functional differentiations within the building (Fig. 7). These shells enveloping each other referred to the etymology of the word cami ['mosque'] meaning 'embracing' and 'bringing together'. Arguing that the minaret has also ceased to serve as the high ground from which the call to prayer was performed, they interpreted it as an urban symbol and used it in a singular manner. The transparent mihrab wall was to be covered with timber shaders designed in Ottoman patterns.

Hence the project responded to the requirement of the brief with a claim to present 'reflections of the future in urban scale and those of tradition in the human scale'. It is not hard to detect the resemblence with Dalokay's Kocatepe design here. Although it was deemed quite radical in the 1950s, Dalokay's proposal involved a contemporary interpretation of the traditional mosque image with the central dome and even its four minarets located conventionally to accentuate the four corners of the structure. Akkas and Akkaș, on the other hand, not only proposed a technologically contemporary structural system, but even questioned the traditional form and started afresh on the basis of the functional requirements of prayer and a contemporary interpretation of an urban landmark.

The project actually chosen and currently under construction was also produced by a team of young architects. Designed by Hayriye Gül Totu and Bahar Mizrak, the proposal is almost a copy of the Blue Mosque (Fig. 8). Against criticisms of copying an existing mosque, the deisgners responded that this was not an issue of imitation but of style: 'They think that our design is a Sinan replica; but this is not a copy. This is a style. ${ }^{164}$ Accordingly, style was a matter of choice: 'Some prefer a contemporary modern style and what we embrace is the Turkish-Islamic style ... You cannot question the style of a poet and ask "why do you write epic poems?"' Defining the dome, halfdomes, minarets and the courtyard as essential elements of Turkish-Islamic tradition, the designers argue that every mosque is inspired by another one. Thus, they claim that their use of existing mosques as a source is 'not imitation or replication but inspiration through the continuity of tradition'.

Interestingly, the designers sought to include original elements to differentiate their work. In addition to the six minarets, resembling the Blue Mosque, they proposed a seventh octagonal 'time minaret' on top of the sadırvan ['ablution fountain'] at the centre of the courtyard, which essentially was a clock tower. In addition, the central dome in their proposal was unusually high; almost a full hemisphere above the drum, a departure from the rather flat Ottoman mosque domes.

Erdoğan asked for certain modifications to the project, in consultation with a group of experts 
Architectural mimicry and the politics of mosque building: negotiating Islam and Nation in Turkey Bülent Batuman

Figure 7. Second-prize winning project for Çamlica mosque designed by Süleyman Akkas and Nihal Senkaya Akkas (courtesy of SN Mimarlık).
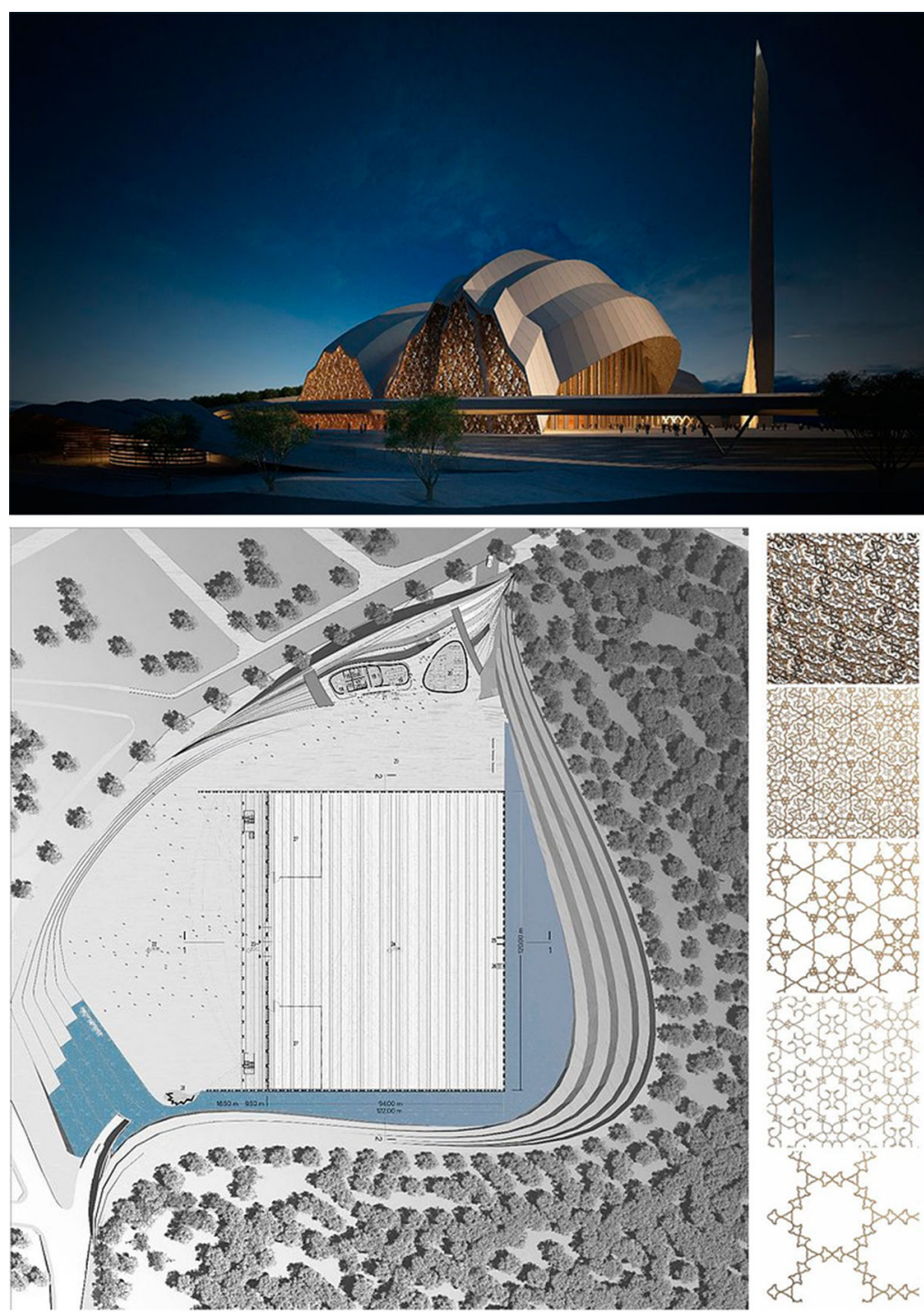

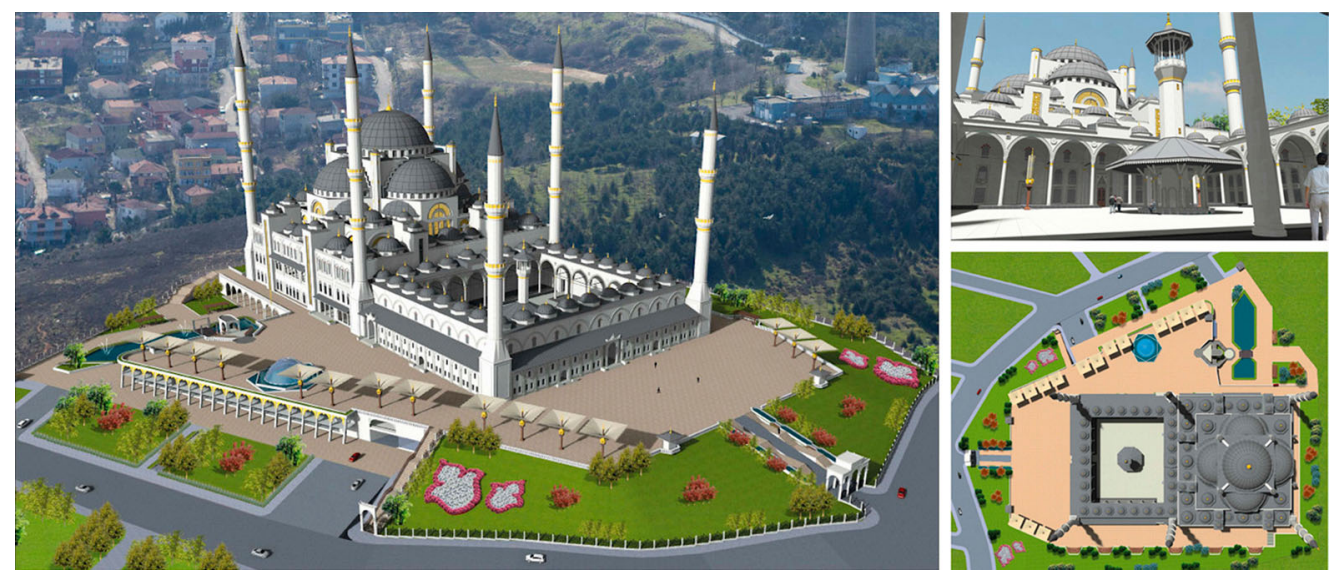

Figure 8. Çamlıca Mosque designed by Hayriye Gül Totu and Bahar Mızrak (source, İstanbul Cami ve EğitimKültür Hizmet Birimleri Yaptırma ve Yaşatma Derneği).

from Istanbul Technical University and Mimar Sinan University. The revisions were supervised by the Ministry of Environment and Urbanism and the outcome was proudly announced by the Minister. Accordingly, the seventh minaret was removed, the central dome was flattened to resemble the Ottoman domes, the entrance to the courtyard was emphasised with a Seljuk-style portal and the proposed canopies shaped like reverse umbrellas bordering the terrace outside the courtyard were replaced with a traditional Ottoman portico. That is, the revisions made by 'experts' following the suggestions of the Prime Minister were mainly aimed at making the mosque look more like classical Ottoman examples. ${ }^{65}$ Once completed, the new mosque will have a 72.5 metre-high dome with a diameter of 34 metres and will accommodate 37, 500 worshippers. The whole complex will cover a site of 57 $000 \mathrm{~m}^{2}$ and include 10 classrooms, a 1,000-person conference hall, a 250-person meeting hall, a library, a museum, a 3,500m $\mathrm{m}^{2}$ exhibition hall and a 3000-car parking garage. The museum is appropriately assigned to be a 'Museum of Turkish-Islamic Art'. There is a web site for the mosque which provides detailed information on the project as well as the ongoing construction. ${ }^{66}$ According to the website the mosque is 'built as an historical monument'. At this size, the mosque will be the fifth largest in the world in terms of enclosed floor space and the largest if its open spaces are included.

As these two cases illustrate, there exists an odd situation wherein the Prime Minister's personal involvement in mosque architecture seems to determine stylistic preferences. Although this is significant for illustrating the concentration of political power in the hands of Erdoğan, what is important for our discussion is the meaning of architectural mimicry within the current context. On the one hand, the 
architectural scene in Turkey is heterogeneous as never before, and does not prioritise mimicry any more. On the other hand, the global setting has witnessed the rise of Islam as a trans-national political force compelling governments to negotiate their ways to establishing a consensus between Islamic opposition and international world order, which made the representation of nationhood in its relationship to Islam an essential topic. On the one hand, a generalised and imagined 'Middle East' and its 'High Islamic' architecture is gradually coming to the fore. ${ }^{67}$ On the other hand, especially in cases where fundamentalist pressure threatens existing establishments, governments seek other Islamic architectural idioms for reference.

The success of Turkey's AKP in developing a particular strand of Islamism harmonious with the global market and the international world order makes it an alternative reference for trans-national Islam; a version compatible with the Western world and a claim to authenticity within the multitude of Islamic representations. Hence, it is not a coincidence to see that, aside from the endeavours of the Directorate of Religious Affairs to export Ottoman replicas (for instance the Tokyo Mosque, 1998-2000, and the Turkish-American Community Center in Washington DC, under construction), governments of various Islamic countries invite Turkish firms to build neo-Ottoman mosques. ${ }^{68}$

Within this context, mimicry of the Ottoman mosque emerges as a simulacrum representing the 'nation in Islam'; imagining the nation as a privileged component of global Islam. It is an instrument in rebuilding 'nation' in the form of millet as well as in an aggressive foreign policy aimed at being influ- ential in the Islamic world. Whilst the Ottoman replica in relation to nationalist conservative nostalgia acknowledged its failure as representation (the longing for a lost golden age), the replica as simulacrum illustrates a self-aware disavowal of this failure. In other words, what we have is the representation of sixteenth-century Ottoman power; yet it is not the subject of nostalgic yearning but a conscious deployment as an imperial(ist) image. This is a claim to authority of representation regarding Islam as well. It addresses both the West and the East, affirming the 'othering' of the Islamic world and attributing to itself a privileged status within it.

The replicated Ottoman mosque reconstructs the millet through the interpellation of citizens with the imperial image conjoining nation and Islam. Yet, this architectural idiom also functions as a recognisable image in the eyes of outsiders. What we find here is different from the re-Orientalism I have discussed above in relation to mosque architecture in the Islamic world. While re-Orientalism affirmed stylistic plurality as representing variations of Islam, here there is a persistent reference to Ottoman imagery as an authentic sign linking the nation to Islam. It is not that the architectural style of a 'golden age' is reproduced to glorify the past. Rather, the simulacrum is constructed in and for the present within the multiplicity of architectural styles. What is at stake here is self-Orientalism as a conscious strategy to identify with the a-historical orientalist image and to utilise it as an instrument of power. Self-Orientalism inevitably refers to existing stereotypes which is crucial for the gaze of the 'other' to recognise. Hence, the orientalised subject voluntarily assumes this identity, only to utilise it as a brand. 


\section{Conclusion}

Mosque architecture has been a political enterprise throughout the twentieth century, especially for the nation states established in the Islamic world. Nation-building processes reflected varying levels of tension between modernist intentions and Islamic identities. In the Turkish case, the mosque was rejected as a national symbol throughout the early republican era. It was only in the post-war years that it was deployed for representing national identity; however, this attempt was influenced by complex power relationships between secularist state structure, government seeking reconciliation with Islam and nationalist conservative worldview gaining grounds within the context of Cold War geopolitics. The outcome was architectural mimicry of the Ottoman Empire in its heyday, which would prevail throughout the following decades. Whilst architectural styles ranging from modernist experiments to historicist repetition were visible throughout the post-colonial Islamic world, architectural mimicry prevailed as the dominant idiom in Turkey.

The mosque was utilised as a political instrument by the Turkish state in the 1990s to build cultural influence in the post-Soviet world. This led to the trans-national circulation of this particular idiom as a representation of (Turkish) 'nation in Islam'. Although it was not effective as a pan-Turkist instrument of foreign policy, it was taken up by the Islamist AKP as a signifier of authenticity within the global variety of Islamic representations. This time, mimicry of the Ottoman mosque generated a simulacrum representing the (privileged) nation in (global) Islam. Different from the nostalgic function- ing of mimicry as a component of nationalist conservative discourse, the replica as simulacrum operates as an imperial image of identification. While it serves the redefinition of the nation in the form of millet as a fusion of Turkishness and Islam internally, it becomes a recognisable image abroad. The simulacrum of the Ottoman mosque operates through self-Orientalism: it represents conscious identification with the stereotype for the gaze of the 'other' to recognise.

The reproduction of the same architectural image within two different historical settings also provides us with findings regarding architectural mimicry in general. I have discussed earlier how mimicry has been tackled particularly in post-colonial theory and in architectural history. Whilst mimicry is defined as a performative act between the coloniser and the colonised, its key drive is the desire to appropriate (at least a portion of) the authority represented by the imitated original. This essential mechanism is also valid in cases of importing modernist architectural forms and urban schemes across the globe as well as the post-modern imitations of historical archetypes. In all of the cases what is at stake is the appeal to the authority of the original. Yet, mimicry indicates a double failure: it associates the copy and the original, and simultaneously acknowledges the difference between them. This, in turn, results in the failure of the copy to become the original and the original to highlight its difference as superior to the copy (and in some cases, there is an intentional play of irony embracing this failure).

As I have argued above, the nostalgic effect produced by the architectural mimicry of classical 
Ottoman mosques within the specific context of Cold War politics in Turkey fits this scheme. However, the current use of the mimicry of Ottoman mosque architecture operates in a significantly different way. It is used as an ideological simulacrum in Islamist politics, which in the current Turkish context serves the fusion of nation and Islam. In discursive terms, it is not possible to revert to essentialism due to the insurmountable gap between ethnic and religious identities. Hence, the mimicry of Ottoman mosque architecture serves as an ideological simulacrum disregarding the mismatch between Turkishness and Islam. Insofar as it is utilised as an effect of political power, the classical Ottoman mosque loses its authority as original. In its current circulation, the Ottoman mosque image is not the copy of the 'real' (sixteenth-century) examples but becomes 'true' within the current global spatio-temporality.

\section{Acknowledgement}

An earlier version of this article was presented at the Writing the Global City: A Tribute to Professor Anthony D. King Conference, Binghamton University, 4th- 5th October, 2013.

\section{Notes and references}

1. 'Bu caminin önemli bir özelliği var!', Haberturk (21/07/ 12); [accessed 25/08/14], http://www.haberturk.com/ ramazan/haber/760529-bu-caminin-onemli-bir-ozelligivar-

2. 'Başbakan'dan üçüncü balkon konușması', Hürriyet (13/06/11); [accessed 25/08/14], http://www.hurriyet. com.tr/gundem/18015912.asp
3. Paul Rabinow, French Modern: Norms and Forms of the Social Environment (Cambridge, Mass., The MIT Press, 1989); Gwendolyn Wright, The Politics of Design in French Colonial Urbansism (Chicago, University of Chicago Press, 1991); Mark Crinson, Empire Building: Victorian Architecture and Orientalism (London, Routledge, 1996); Mark Crinson, Modern Architecture and the End of Empire (Burlington, Ashgate, 2003).

4. Timothy Mitchell, Colonizing Egypt (Berkeley, Los Angeles, University of California Press, 1988).

5. Thomas R. Metcalf, An Imperial Vision: Indian Architecture and Britain's Raj (Berkeley, University of California Press, 1989); Mia Fuller, Moderns Abroad: Architecture, Cities, and Italian Imperialism (London, Routledge, 2007)

6. Homi K. Bhabha, 'Of Mimicry and Man: The Ambivalence of Colonial Discourse', in The Location of Culture (London, New York, Routledge, 1994), p. 126.

7. Bernd Nicolai, Moderne und Exil: Deutschsprachige Architekten in der Türkei 1925-1955 (Berlin, Verlag für Bauwesen, 1998); Sibel Bozdoğan, Modernism and Nation Building: Turkish Architectural Culture in the Early Republic (Seattle, University of Washington Press, 2001).

8. These transfers were not simple processes of importation but 'translations' contingent upon uneasy negotiations: see, Esra Akcan, Architecture in Translation: Germany, Turkey, and the Modern House (Durham, NC, Duke University Press, 2012).

9. Meltem Ö. Gürel, 'Architectural mimicry, spaces of modernity: the Island Casino, Izmir, Turkey', The Journal of Architecture, 16, 2 (2011), pp. 165-190.

10. Sharon Zukin, The Cultures of Cities (Cambridge, Mass., Blackwell, 1995); Michael Sorkin, ed., Variations on a Theme Park: The New American City and the End of Public Space (New York, Hill and Wang, 1992).

11. This trend was famously given theoretical form by Frederic Jameson as 'pastiche': Frederic Jameson, 'Post- 
modernism or the Cultural Logic of Late Capitalism', New Left Review, 146 (July-August, 1984), pp. 53-92.

12. For post-modern historicism in residential architecture, see Sibel Bozdoğan, 'Vernacular Architecture and Identity Politics: The Case of the "Turkish House"', Traditional Dwellings and Settlements Review, 7 (Spring, 1996), pp. 7-18; Nuray Özaslan, Aysu Akalın, Christopher Wilson, 'Postmodernism and Consumer Culture: Image-production via Residential Architecture in post1980s Turkey', African Journal of Business Management, 5 (2011), pp. 2597-2606; Sibel Bozdoğan, Esra Akcan, Turkey: Modern Architectures in History (London, Reaktion Books, 2012), pp. 223-233. For an example of theme parks based on architectural replicas, see Ipek Türeli, 'Modeling Citizenship in Turkey's Miniature Park', Traditional Dwellings and Settlements Review, 17 (2006), pp. 55-69.

13. Bianca Bosker, Original Copies: Architectural Mimicry in Contemporary China (Hong Kong, University of Hawaii Press, 2013).

14. H. Bahbha, 'Of Mimicry and Man', op. cit., pp. 122-3.

15. Erik Jan Zürcher, Turkey: A Modern History (London, New York, I. B. Tauris, 2007), pp. 166-205.

16. For a discussion of the selective approporiation and incorporation of the Ottoman past into the the nationbuilding process see, Nicholas Danforth, 'Multi-Purpose Empire: Ottoman History in Republican Turkey', Middle Eastern Studies, 50 (2014), pp. 655-678.

17. For a recent study of Sinan in English, see, Gülru Necipoğlu, The Age of Sinan: Architectural Culture in the Ottoman Empire (London, Reaktion Books, 2005). For the invention of Sinan as a nationalist myth, see, Uğur Tanyeli, 'Mimar Bireyin Sahte Tarihi ve Sinan', in Mimarlığın Aktörleri: Türkiye 1900-2000 (Istanbul, Garanti Galeri, 2007), pp. 34-39.

18. Fikret Karaman, 'The Status and Function of the PRA in the Turkish Republic', The Muslim World, 98 (2008), p. 286.
19. Tanıl Bora, Türk Sağının Üç Hali: Milliyetçilik, Muhafazakarlık, islamcılık (Istanbul, Birikim, 2009).

20. Yüksel Tașkın, Anti-Komünizmden Küreselleșme Karșıt/ı̆ı̆na Milliyetçi Muhafazakar Entelijansiya (Istanbul, Illetişim, 2007).

21. İsmail Hami Danișmend, 'Ayasofya'nın Laikliği', Milliyet, 2 (21/02/52); issmail Hami Danșmend, 'Ayasofya Meselesi', Milliyet, 2 (14/07/52).

22. 'Anıtlar Derneği Taksimde Bir Cami Yaptırıyor', Milliyet (24/03/55).

23. Oktay Ekinci, Bütün Yönleriyle Taksim Camisi Belgeseli (Istanbul, Çagdaş Yayınları, 1997), pp. 13-14.

24. I borrow the term from Yalman, who has used it in a different context: see, Galip L. Yalman, 'Tarihsel Bir Perspektiften Türkiye'de Devlet ve Burjuvazi: Rölativist Bir Paradigma mı Hegemonya Stratejisi mi?', Praksis, 5 (Winter, 2002), pp. 7-23.

25. General Directorate of Press, Büyük Ankara'ya Doğru (Ankara, General Directorate of Press, 1957).

26. Bülent Batuman, The Politics of Public Space: Domination and Appropriation in and of Kızılay Square (Saarbrücken, VDM Verlag, 2009); Ali Cengizkan, "The production of a mise en scène for a nation and its subjects: Clemens Holzmeister et al. in the Ministries Quarter for Ankara, Turkey', The Journal of Architecture, 15, 6 (2010), pp. 731-770.

27. 'Bașvekil Ankara Camii için 100 bin lira teberru etti', Milliyet, 1 (15/02/57).

28. For details of the design see, Selim iltuș, Nazif Topçuoğlu, 'Kocatepe Camii Muamması', Mimarlık, 135 (1976), p. 67; Jale N. Erzen, Aydan Balamir, 'Contemporary Mosque Architecture in Turkey', in, I. Serageldin, J. Steele, eds, Architecture of the Contemporary Mosque (London, Academy Editions, 1996), pp. 100-117; Michael E. Meeker, 'Once There was, Once There wasn't: National Monuments and Interpersonal Exchange', in, S. Bozdoğan, R. Kasaba, eds, Rethinking Modernity and National Identity in 
Turkey (Seattle, University of Washington Press, 1997), pp. 157-191; İmdat As, 'The Digital Mosque: A New Paradigm in Mosque Design', Journal of Architectural Education, 60 (2006), pp. 54-66.

29. 'Caminin Minaresi Füzeye Benzetildi', Milliyet, 1-2 (19/ $01 / 65$.

30. Hüsrev Tayla, the designer of the final version, claimed in a later interview that while he was working on a 'contemporary' proposal for the competition, he turned to classical mosque architecture after reading a newspaper article mentioning that the authorities desired 'something similar to Süleymaniye': see Emine Merdim Yılmaz, 'Hüsrev Tayla ile Söyleși: Kocatepe Camisi'ni Yaptım ama Bu Hiçbirinin Kopyası Değil', Arkitera.com (2009); [accessed 25/08/14], http://v3.arkitera.com/s170-kocatepe-camisini-yaptimama-bu-hicbirinin-kopyasi-degil.html

31. For a quantitative comparison of the two mosques, see Imdat As, 'The Digital Mosque', op. cit.

32. For a discussion of the professional reactions to both of the proposals for Kocatepe Mosque, see S. Bozdoğan and E. Akcan, Turkey, op. cit., pp. 197-200.

33. It is crucial to mention a third approach in contemporary Turkish mosque architecture. Between modernist experiments and imitations of classical Ottoman examples, a third way represented by the work of Turgut Cansever was to reproduce the classical mosque with its original construction techniques. Ibid., pp. 220-223.

34. Mandaville cautions that the use of the term should not lead to the neglect of important historical continuities in the Islamic world: see Peter G. Mandaville, Global Political Islam (London, New York, Routledge, 2007), p. 89.

35. Ibid., pp. 49-95.

36. The international literature on mosque architecture is mostly limited to formal analyses cataloguing examples historically and geographically. For information regard- ing the mosques mentioned, see ismail Serageldin, James Steele, eds, Architecture of the Contemporary Mosque (London, Academy Editions, 1996); Martin Frishman, Hasan-Uddin Khan, eds, The Mosque: History, Architectural Development \& Regional Diversity (New York, Thames and Hudson, 1994); Renata Holod, Hasan-Uddin Khan, eds, The Mosque and the Modern World: Architects, Patrons and Designs since the 1950s (New York, Thames and Hudson, 1997).

37. The deployment of Orientalism by the Orientals has been discussed as 're-Orientalism' and 'self-Orientalism' by different authors: see, for instance, Lisa Lau, 'Re-Orientalism: The Perpetration and Development of Orientalism by Orientals', Modern Asian Studies, 43 (2009), pp. 571-590; Lisa Lau, Ana Cristina Mendes, Re-Orientalism and South Asian Identity Politics: The Oriental Other Within (London, New York, Routledge, 2011); Koichi Iwabuchi, 'Complicit Exoticism: Japan and Its Other', The Australian Journal of Media \& Culture, 8 (1994), pp. 49-82; Plamen K. Georgiev, Self-Orientalization in South East Europe (Wiesbaden, Springer VS, 2012). Below, I will differentiate between 're-Orientalism' and 'self-Orientalism' to define the specificity of Turkey's AKP.

38. For a discussion of the negotiation between local and global Islams through mosque architecture in Indonesia, see Abidin Kusno, '"The Reality of One-Which-isTwo": Mosque Battles and other Stories', Journal of Architectural Education, 57 (2003), pp. 57-67.

39. The 1960 s also saw the emergence of successful modernist mosque designs, albeit at very small scales. Amongst these are the mosque in Kınalıada (one of the Prince's Islands) and the Etimesgut Mosque in Ankara, built in 1964 and 1965 respectively. These two mosques were valued by architectural historians as fine examples of modern mosque architecture: See J. N. Erzen, A. Balamir, 'Contemporary Mosque Architecture in Turkey', op. cit. 
40. Directorate of Religious Affairs, 50 Yllda Dini Yapılar (Ankara, Directorate of Religious Affairs, 1974).

41. 'Her Üniversiteye bir Cami', Milliyet, 2 (28/01/86); '"ODTÜ"den Rabıta'nın 210 Milyonuna "Hayır"', Milliyet, 7 (24/03/87).

42. Evren: "Büyük Eserleri Yașatacak Sanatkarlar Yetiștireceğiz"', Milliyet, 8 (19/07/82).

43. Meanwhile, it was decided to build a mosque inside the National Assembly grounds in 1984. The job was assigned to Behruz Çinici (together with Can Çinici), the prominent Turkish architect who had recently designed the Public Relations Building of the Assembly. The architects produced a modernist scheme interpreting the traditional dome with a stepped pyramid and the minaret with a poplar tree. Although this proposal was also met with scepticism from the right-wing press, the design was praised by the architectural community and it was awarded the Aga Khan Award in 1995. The Parliament Mosque represents the epitome of the modernist mosque design tradition with its design quality as well as symbolic location inside the Parliament grounds which made it impossible to overlook like the earlier examples of the 1960s. For a discussion on the significance of the Parliament Mosque in Turkish architecture, see S. Bozdoğan, E. Akcan, Turkey, op. cit., pp. 217-223.

44. Cihan Tuğal, Passive Revolution: Absorbing the Islamic Challenge to Capitalism (Stanford, Stanford University Press, 2009).

45. Turkish Foundation of Religious Affairs, 20. Yilında Türkiye Diyanet Vakfı (Ankara, Turkish Foundation of Religious Affairs, 1995).

46. The Directorate published an album documenting the mosques built in this period: Directorate of Religious Affairs, Orta Asya Türk Cumhuriyetleri, Balkan-Kafkas Ülkeleri Camiler ve Eğitim Merkezleri Albümü (Ankara, Directorate of Religious Affairs, 2003). An earlier publication included mosques built in Europe,
America and Australia: Directorate of Religious Affairs, Yurtdıșı Camiler Albümü (Ankara, Directorate of Religious Affairs, 1997).

47. For instance, whilst the earlier Eurasian Islamic Council (EIC) resolutions referred to the delegates as 'representatives of Turkic and Muslim communities', the final resolution of the seventh summit in 2009 referred to them as 'representatives of Muslim countries and societies of Eurasia that are connected by religious, historical and cultural ties': Directorate of Religious Affairs, 'VII. Avrasya İslam Şurası Sonuç Bildirisi' (15/ 05/09); [accessed 26/08/14], http://www. diyanet.gov. tr/tr/icerik/vii-avrasya-islam-surasi-sonuc-bildirisi/6208. The EIC was an initiative of the Turkish state and organised by the Directorate for the first time in 1995.

48. For the former view, see Michael Rubin, 'Shifting Sides?: The Problems of Neo-Ottomanism', National Review (10/08/04), http://www.meforum.org/628/ shifting-sides. For the latter, see Behlül Özkan, 'Turkey, Davutoglu and the Idea of Pan-Islamism', Survival: Global Politics and Strategy, 56 (August-September, 2014), pp. 119-140.

49. Sonol Korkut, 'The Diyanet of Turkey and Its Activities in Eurasia after the Cold War', Acta Slavica laponica, 28 (2010), pp. 117-139.

50. The figures are taken from the web site of the Mass Housing Administration (toki.gov.tr).

51. The Foundation for Religious and Social Services was originally established as 'Tokyo Mosque Foundation' in 1997. After the Foundation successfully finished the construction of the Tokyo Mosque, it was reorganised in 2003. See, Foundation for Religious and Social Services, Dini ve Sosyal Hizmetler Vakfı (Ankara, Turkish Foundation of Religious Affairs, 2007).

52. 'Samsun'da 120 camide spor', DHA (26/07/13); [accessed 26/08/14], http://www.dha.com.tr/samsunda120-camide-spor_504143.html. 
53. The successful strategy emphasising the shared Islamic identity which helped improve relations with the Turkic republics of Central Asia did not work with the highly politicised Kurdish movement. The Kurds responded with an unprecedented action of civil disobedience. Thousands performed the Friday prayers outside the mosques in 2011, in response to the government's attempt to use the mosque as an instrument of assimilation. The Friday sermons were given in Kurdish and the action was pursued in various Kurdish provinces. " Sivil Cuma Namazı" Kılındı', bianet.org (08/04/11); [accessed 26/08/14], http://www.bianet.org/bianet/ siyaset/129155-sivil-cuma-namazi-kilindi. A similar backlash was experienced with the Alevis: Alevism is not recognised as a distinct religion but as a branch of Islam by the Directorate of Religious Affairs, therefore its shrines (Cemevi) are not officially accepted as temples. Whilst the Alevis demand official status for the Cemevi, the government came up with an idea to build mosque-Cemevi complexes, with the claim that this would serve the association of believers. Construction of the first of these complexes began in an Alevi quarter in Ankara in September, 2013. It was perceived as an attempt to force the Alevis to attend the mosque and was met with a violent response. See, 'Alevi örgütlerinden ortak açıklama: Camicemevi projesi kabul edilemez', SOL Portal (10/09/13); [accessed 26/08/14], http://haber.sol.org.tr/devlet-vesiyaset/alevi-orgutlerinden-ortak-aciklama-cami-cemeviprojesi-kabul-edilemez-haberi-79400.

54. This is not to state that modernist schemes were easily implemented. For instance, Sayın's mosque design in Malatya, providing a contemporary interpretation of Seljuk mosque architecture, was cancelled while under construction by command of the Prime Minister, Erdoğan, since it lacked a dome. Another case was the winning project of the competition for Șișli Halide Edip Adıvar Islamic
Compex (2011) which was also not built because it did not have a dome.

55. In 2005, the Directorate of Religious Affairs organised a panel on mosque architecture in collaboration with Bilkent University in Ankara. This was followed by a 'Consultation Meeting on Mosque Projects' convened jointly by the Directorate and the Foundation for Religious and Social Services on $10^{\text {th }}-11^{\text {th }}$ July, 2006. See, Foundation for Religious and Social Services, Cami Projeleri İstisare Toplantısı (Ankara, Foundation of Religious and Social Services, 2007). These endeavours at developing a new architectural idiom for contemporary mosques culminated in a larger event in Istanbul in 2012, with the title 'First National Symposium for Mosque Architecture', which could also be translated as the 'first symposium for national mosque architecture'

56. For a detailed discussion of the Taksim mosque, see Bülent Batuman, '"Everywhere is Taksim": The Politics of Public Space from Nation-building to Neoliberal Islamism and Beyond', Journal of Urban History, 41 (2015), pp. 881-907.

57. 'İste Taksim Camisi!', Arkitera.com (16/05/12); [accessed 27/08/14], http://www.arkitera.com/haber/8200.

58. 'Mosque of the Republic \& Museum of Religions, Istanbul, Turkey', http://alparchitects.com.tr/eng/proje_ detay.asp?id=27; [accessed 31/08/15].

59. 'Erdoğan, Taksim Camisi projesini beğenmedi', Arkitera.com (28/06/12); [accessed 27/08/14], http:// www.arkitera.com/haber/8934/erdogan-taksim-camisiprojesini-begenmedi.

60. 'Yeni Taksim Camii Basbakan'ın Masasında', Radikal (22/09/13); http://www.radikal.com.tr/turkiye/yeni_ taksim_camii_basbakanin_masasinda-1152005

61. 'İstanbul'a Dev Cami Geliyor', Radikal (30/05/12, http:// www.radikal.com.tr/politika/istanbula_dev_cami_geliyor1089547

62. 'İstanbul Çamlıca Camii Mimari Proje Yarıșması', Arkitera.com (23/07/12); [accessed 31/08/15], 
http://www.arkitera.com/yarisma/239/istanbul-camlicacamii-mimari-proje-yarismasi

63. Derya Yazman, 'Ne Yapılması Gerektiğini Göstermek Istedik', Arkitera.com (26/11/12); [accessed 31/08/15], http://www.arkitera.com/haber/1 1007/ne-yapilmasi-ger ektigini-gostermek-istedik.

64. 'Çamlıca'ya yapılacak cami taklit mi?', Milliyet (16/11/ 12); [accessed 31/08/15], http://www.milliyet.com.tr/ camlica-ya-yapilacak-cami-taklit-mi-/gundem/gunde mdetay/16.11.2012/1628040/default.htm

65. 'Erdoğan'ın Çamlıca'sı', Arkitera.com (20/02/13); [accessed 27/08/14], http://www.arkitera.com/haber/ 12243/erdoganin-camlicasi.
66. See http://www.istanbulcami.com/

67. A good example is the Putra Mosque in Putrajaya, the new federal administrative centre of Malaysia, which simultaneously refers to a mosque in Uzbekistan, the Persian-Islamic architecture of the Safavids and the minaret of the Sheikh Omar Mosque in Baghdad. See, Sarah Moser, 'Putrajaya: Malaysia's new federal administrative capital', Cities, 27 (2010), p. 292.

68. See, for instance, the İmam el Buhari Mosque in Yekaterinburg (2002) and the Ahmed Kadyrov Mosque in Grozny (2008). 